\title{
MODELING OF THE PETROLEUM SYSTEM IN THE CAUVERY BASIN, SRI LANKA
}

\author{
UPUL PREMARATHNE \\ Department of Oceanography and Marine Geology, Faculty of Fisheries and Marine Sciences \& \\ Technology, University of Ruhuna, Wellamadama, Matara, Sri Lanka \\ E-mail:premarat@yahoo.com
}

(Received 17 $7^{\text {th }}$ July 2020; accepted 03 ${ }^{\text {rd }}$ March 2021)

\begin{abstract}
A part of the southeastern onshore area of India and the northwestern onshore area of Sri Lanka, and the Palk Strait come under the Cauvery Basin. The Indian side of the Cauvery Basin has proven hydrocarbon reserves, while the Sri Lankan sector remains relatively under-explored. Only six exploration wells drilled in the Sri Lankan sector from 1972 to 1981 was dry. Since little further exploration has taken place from 1981 to this date, the existence of an active petroleum system in the Sri Lanka sector of the basin is not known. The objective of this study was to simulate the petroleum system in the Sri Lankan sector of the Cauvery Basin on Petromod 1D software (v.12.2) using data from unpublished reports and data in the public domain. The model was validated using the measured vitrinite reflectance data. Results of the study showed that Albian and Late Cretaceous shale in the Pesalai area have relatively higher hydrocarbon source potential and that hydrocarbon exploration in the Sri Lankan sector of the Cauvery Basin should mainly target Cretaceous and Eocene clastic and carbonate reservoirs associated with faults and anticlinal traps. Hydrocarbon potential in the Pesalai area is relatively higher than that in the Palk-Bay area.
\end{abstract}

Keywords: Cauvery Basin, petroleum system, hydrocarbons, Pesalai, Sri Lanka

\section{INTRODUCTION}

The Cauvery Basin encompasses the southeastern onshore area of India, the northwestern onshore area of Sri Lanka, and the offshore area between the two countries (Fig. 1). Sri Lankan sector of the Cauvery Basin (Fig. 1) extends over $15,000 \mathrm{~km}^{2}$, out of which its onshore area extends up to around $\sim 20-30 \mathrm{~km}$ inland from the NW coastal line. The offshore areas of the basin lie in shallow water up to the $200 \mathrm{~m}$ isobath.

The Cauvery Basin is a pericretonic failed rift basin (Sastri et al., 1973; 1981), which has been evolved due to multiphase rifting between IndoLanka landmasses (Baillie et al., 2003). The onset of rifting that gave rise to the Palk Strait (see Fig. 1) was initiated around 132 Ma (Desa et. al., 2018) and ceased around $90 \mathrm{Ma}$ (Chakraborty and Sarkar, 2018; Raju et al., 2018; Chaudhuri et al., 2010). Paleomagnetic measurements from the Pesalai-1 well (Fig. 1) suggest that Sri Lanka had migrated around
$2400 \mathrm{~km}$ from $16^{\circ} \mathrm{S}$ during the Paleogene to $8^{\circ}$ $\mathrm{N}$ at present (Cantwell et al., 1978). The intervening NW-SE trending horsts/ basement ridges, which divide the Cauvery Basin into subbasins/ depressions (Fig. 1), have been formed during the seafloor spreading between India and Antarctica in the early Cretaceous (Lal et al., 2009).

Stratigraphy, tectonic setting, and hydrocarbon prospectivity of the Indian side of the Cauvery Basin have been addressed in detail by Sastri et al. (1973; 1981); Chandra et al. (1991); Ramana et al. (1995); Murthy et al. (2008); Rana et al. (2008); Lal et al. (2009); Rao, et al. (2010); Chaudhuri et al. (2010); Chakraborty et al. (2018); Bastia and Radhakrishna, (2012), etc. Those facts on the Sri Lankan counterpart have been addressed by Cantwell et al., (1978); Premarathne, (2008, 2015, 2017, 2020); Bandara et al., 2020). Most of this information comes from gravity, magnetic and seismic data, and well reports gathered as a result of hydrocarbon exploration in the basin. 
Six explorations wells were drilled in the Sri Lanka side of the basin during the $1972-1981$ period (see Fig. 1 for well locations). Though some gas shows were recorded in the Pesalai wells, none of them penetrated an economically feasible hydrocarbon deposit.

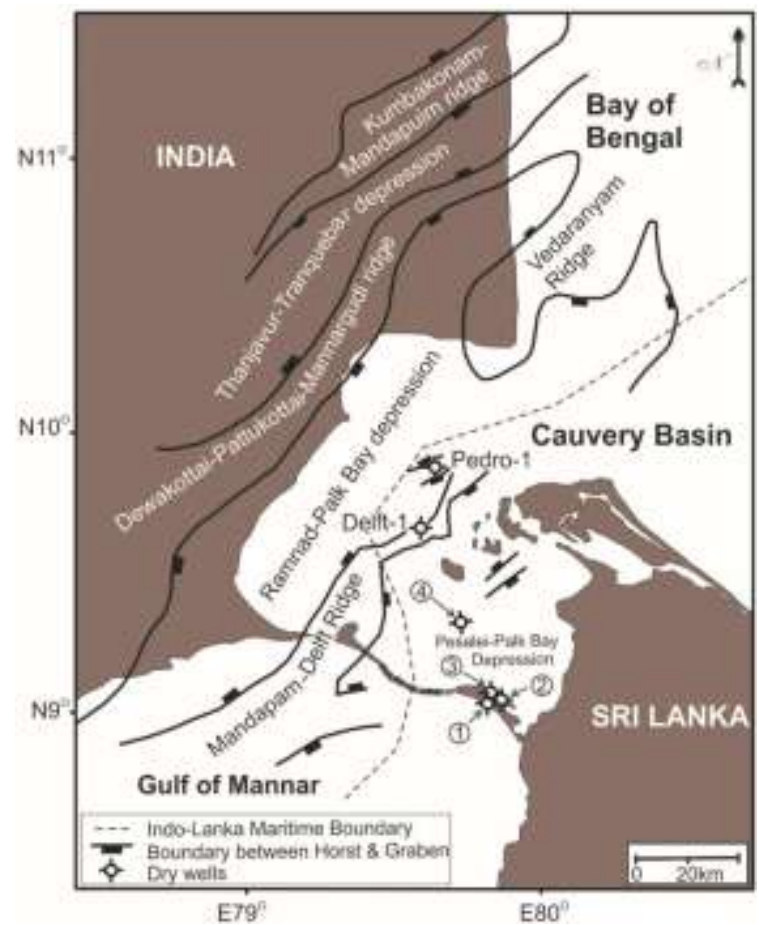

Fig.1. Sri Lankan side of the Cauvery Basin and hydrocarbon exploration wells drilled in it (modified after Premarathne et al., 2015) Encircled 1, 2, 3, and 4 in denotes Pesalai-1, 2, and 3 wells, and Palk Bay-1 well, respectively.

Little further exploration has taken place in the Sri Lanka side of the basin since 1981. However, the Indian sector of the basin, which began hydrocarbon exploration almost the same time as the Sri Lankan sector, is now producing both oil and natural gas (Chandra et al., 1991). The Ramnad-Palk-Bay-Nagapattinam depression mainly under the Indian Jurisdiction (Fig. 1) is the most prolific petroliferous sub-basins (Murthy et al., 2008). Relatively a small part of this sub-basin comes under the Sri Lankan jurisdiction (see Fig. 1). PH-9-1 well, which has discovered oil, is located at the Indian side of the Ramnad-Palk Bay-Nagapattinam depression, just $21 \mathrm{~km}$ northwest of the Indo-Lanka maritime boundary (Ramana et al., 1995). It is the hydrocarbon discovery in the Indian side of Cauvery Basin located closest to Sri Lanka.

Resuming hydrocarbon exploration in the Sri Lankan side of the Cauvery Basin has been under consideration since the discovery of two natural gas deposits in the Mannar Basin, which is located south of the Cauvery Basin. These discoveries in 2011 confirmed the occurrence of an active petroleum system in the Mannar Basin (Mohapatra et al., 2012; Premarathne et al., 2013). Both Cauvery and Mannar Basins share similar tectonic histories (Premarathne et al., 2016; Ratheesh-Kumara et al., 2020). Many researchers (e.g. Chandra et al., 1991; Chari et al., 1995; Baillie et al., 2003; Premarathne, 2008; Rana et al., 2008; Rao et al., 2010) consider the Mannar basin to be the southern extension of the Cauvery Basin. The petroleum geology of the Sri Lankan sector of the basin has been addressed by Cantwell et al. (1978) and Premarathne $(2015,2020)$. However, as to whether the Sri Lankan sector of the Cauvery Basin has an active petroleum system of its own or whether the petroleum system in the Indian side extends towards the Sri Lankan side still remains unknown due to the lack of well penetration and scarcity of data. The objective of this study was to simulate the hydrocarbon generation, expulsion, and the timing of hydrocarbon expulsion, and thereby to understand the possible petroleum system that may occur in the Sri Lankan sector of the Cauvery Basin.

\section{METHODOLOGY}

PetroMod 1D software (v. 12.2) was used to simulate the rate and the timing of hydrocarbon generation and the amount of hydrocarbon expulsion from potential source rocks penetrated by the Pesalai-1, Palk-Bay-1, Delft-1, and Pedro-1 wells. The four wells are located along a line that runs north-south direction over the Sri Lankan sector of the Cauvery Basin (see Fig. 1). Though the Pesalai-3 has been the deepest well $(\sim 2850 \mathrm{~m})$ drilled at the basin in Sri Lanka, it and the Pesalai- 2 well were excluded from this study due to the lack of availability of data, such as lithology, TOC, vitrinite reflectance, maceral composition, etc. Premarathne (2020) has modeled the burial, thermal and heat flow history of the study area on PetroMod 1D software using data from the Pesalai-1, PalkBay-1, Delft-1, and Pedro-1 wells. The same input data (lithology units and their depositional ages, degree of erosion and hiatus of unconformities) and boundary conditions(paleo water depths, the temperature at SedimentWater Interface (SWI) and heat flows, etc.) were used for this study (Tables $1 \& 2$ ). 
Table 1. Input data used in this study for Pesalai -1 and Palk Bay-1 wells $(P S E=$ petroleum system events, Thick. $=$ formation thickness, Depo. $=$ deposition in Ma, Quat. = Quaternary, Plio = Pliocene, Mio. = Miocene, Turo. = Turonian, Alb. Albian, Apt, and Aptian. L., M., and E., stand for Late, Middle and, respectively). Erosion is in Ma. The unit of $\mathrm{HI}$ is $\mathrm{mgHC} / \mathrm{g}$ TOC (data in the first 10 columns are from Premarathne, 2020).

Pesalai-1

\begin{tabular}{|c|c|c|c|c|c|c|c|c|c|c|c|c|}
\hline Layer & Top & Base & $\begin{array}{c}\text { Thick. } \\
(\mathrm{m})\end{array}$ & $\begin{array}{c}\text { Eroded } \\
(\mathrm{m})\end{array}$ & $\begin{array}{c}\text { Depo. } \\
\text { from }\end{array}$ & $\begin{array}{c}\text { Depo. } \\
\text { to }\end{array}$ & $\begin{array}{c}\text { Eroded } \\
\text { from } \\
\end{array}$ & $\begin{array}{c}\text { Eroded } \\
\text { to } \\
\end{array}$ & lithology & PSE & $\begin{array}{c}\text { TOC } \\
(\%)\end{array}$ & HI \\
\hline Quaternary & 0 & 50 & 50 & & 2.6 & 0 & & & Sandstone (qtz) & Overburden Rock & & \\
\hline Pliocene to L. Mio & 50 & 333 & 283 & & 11.6 & 2.6 & & & Sandstone (qtz) & Overburden Rock & & \\
\hline Eocene & 929 & 1287 & 358 & 176 & 56 & 33.9 & 33.9 & 23 & Sandstone & Overburden Rock & & \\
\hline Paleocene & 1287 & 1337 & 50 & & 58 & 56 & & & Shale (typical) & Seal Rock & & \\
\hline L.Cret._1 & 1337 & 2000 & 663 & 361 & 92 & 70 & 70 & 58 & Shale (typical) & Source Rock & 3 & 100 \\
\hline Albian-2 & 2298 & 2454 & 156 & & 110 & 105 & & & Shale (typical) & Source Rock & 4.5 & 100 \\
\hline Albian_3 & 2454 & 2554 & 100 & & 113 & 110 & & & Conglomerate & Underburden Rock & & \\
\hline
\end{tabular}

Palk Bay-1

\begin{tabular}{|c|c|c|c|c|c|c|c|c|c|c|c|c|}
\hline Layer & Top & Base & $\begin{array}{c}\text { Thick. } \\
(\mathrm{m})\end{array}$ & $\begin{array}{c}\text { Eroded } \\
(\mathrm{m})\end{array}$ & $\begin{array}{r}\text { Depo. } \\
\text { from }\end{array}$ & $\begin{array}{c}\text { Depo. } \\
\text { to }\end{array}$ & $\begin{array}{c}\text { Eroded } \\
\text { from }\end{array}$ & $\begin{array}{c}\text { Eroded } \\
\text { to }\end{array}$ & lithology & PSE & $\begin{array}{c}\text { TOC } \\
(\%)\end{array}$ & HI \\
\hline M-E. Mio & 258 & 904 & 646 & & 23 & 9 & & & Marl & Overburden Rock & & \\
\hline Eocene & 1415 & 1641 & 226 & & 56 & 33.9 & & & Limestone (shaly) & Reservoir Rock & & \\
\hline Maastrichtian & 1641 & 1850 & 209 & 310 & 72 & 67 & 67 & 56 & Shale (typical) & Source Rock & 0.6 & 120 \\
\hline Campanian & 1850 & 1931 & 81 & & 75 & 72 & & & Shale (typical) & Source Rock & 0.4 & 75 \\
\hline
\end{tabular}


Table 2. Input data used in this study for Delft -1 and Pedro-1 wells. Abbreviations in the table are the same as those in Table 1 (data in the first 10 columns are from Premarathne, 2020).

Delft-1

\begin{tabular}{|c|c|c|c|c|c|c|c|c|c|c|c|c|}
\hline Layer & Top & Base & $\begin{array}{l}\text { Thick. } \\
\text { (m) }\end{array}$ & $\begin{array}{c}\text { Eroded } \\
(\mathrm{m})\end{array}$ & $\begin{array}{r}\text { Depo. } \\
\text { from }\end{array}$ & $\begin{array}{c}\text { Depo. } \\
\text { to }\end{array}$ & $\begin{array}{c}\text { Eroded } \\
\text { from }\end{array}$ & $\begin{array}{c}\text { Eroded } \\
\text { to }\end{array}$ & lithology & PSE & $\begin{array}{c}\text { TOC } \\
(\%)\end{array}$ & HI \\
\hline Quat. to Pliocene & 35 & 295 & 260 & & 5.3 & 0 & & & Sandstone (typical) & Overburden Rock & & \\
\hline Middle Miocene & 295 & 571 & 276 & 216 & 16 & 10 & 10 & 5.3 & Limestone & Overburden Rock & & \\
\hline Early Miocene & 571 & 899 & 328 & & 23 & 16 & & & Shale (typical) & Overburden Rock & & \\
\hline L. Oligocene & 899 & 1099 & 200 & & 28 & 23 & & & Shale (typical) & Seal Rock & & \\
\hline Ealry Oligocene & 1099 & 1213 & 114 & & 31.8 & 28 & & & Limestone (shaly) & Reservoir Rock & & \\
\hline Early Oligocene & 1213 & 1276 & 63 & & 33.9 & 31.8 & & & Sandstone (clay rich) & Reservoir Rock & & \\
\hline Albian & 1276 & 1322 & 46 & 1650 & 101.6 & 100 & 100 & 33.9 & Limestone & Reservoir Rock & & \\
\hline Albian & 1322 & 1392 & 70 & & 104 & 101.6 & & & Sandstone (typical) & Reservoir Rock & & \\
\hline Albian & 1392 & 1592 & 200 & & 111 & 104 & & & Conglomerate & Overburden Rock & & \\
\hline Albian -Aptian & 1592 & 1734 & 142 & & 116 & 111 & & & Shale (typical) & Source Rock & 2.1 & 32 \\
\hline
\end{tabular}

Pedro-1

\begin{tabular}{|c|c|c|c|c|c|c|c|c|c|c|c|c|}
\hline Layer & Top & Base & $\begin{array}{l}\text { Thick. } \\
\text { (m) }\end{array}$ & $\begin{array}{c}\text { Eroded } \\
(\mathrm{m})\end{array}$ & $\begin{array}{r}\text { Depo. } \\
\text { from }\end{array}$ & $\begin{array}{c}\text { Depo. } \\
\text { to }\end{array}$ & $\begin{array}{c}\text { Eroded } \\
\text { from }\end{array}$ & $\begin{array}{c}\text { Eroded } \\
\text { to }\end{array}$ & lithology & PSE & \multicolumn{2}{|c|}{$\begin{array}{cc}\text { TOC } & \mathbf{H} \\
(\%) & \\
\end{array}$} \\
\hline Quat.-Pliocene & 37 & 279 & 242 & & 5.3 & 0 & & & Sandstone (typical) & Overburden Rock & & \\
\hline Miocene & 279 & 660 & 381 & & 14.8 & 5.3 & & & Limestone & Overburden Rock & & \\
\hline Miocene & 660 & 713 & 53 & & 16.1 & 14.8 & & & Shale (typical) & Seal Rock & & \\
\hline Miocene & 713 & 991 & 278 & & 23 & 16.1 & & & Limestone (shaly) & Reservoir Rock & & \\
\hline Oligocene & 991 & 1051 & 60 & & 27.26 & 23 & & & Shale (typical) & Seal Rock & 0.7 & 45 \\
\hline Oligocene & 1051 & 1081 & 30 & & 29.39 & 27.26 & & & Limestone & Reservoir Rock & & \\
\hline Oligocene & 1081 & 1144 & 63 & & 33.9 & 29.39 & & & $\begin{array}{l}\text { Shale (typical) } \\
\text { Sandstone (clay }\end{array}$ & Seal Rock & 0.71 & 45 \\
\hline Eocene & 1144 & 1293 & 149 & & 48 & 33.9 & & & rich) & Reservoir Rock & & \\
\hline Albian & 1293 & 1417 & 124 & 920 & 108 & 102 & 102 & 48 & Shale (typical) & Source Rock & 0.85 & 100 \\
\hline
\end{tabular}


Sediment compaction during the progressive burial and the change in thermal conductivity, porosity, and permeability of sediments with increasing burial were simulated using default values available in the software database.

Premarathne (2015) has reported the Total Organic Carbon (TOC), Hydrogen Index (HI), and maceral composition of sediment samples from the four wells. Based on the hydrocarbon source character and lithology data available in Premarathne (2015), potential hydrocarbon source rocks and their average TOC and $\mathrm{HI}$ values were determined (see tables 1 and 2). Well data reported in Premarathne (2015) show that sediments from the four wells have a mixture of types II and III kerogen. However, the kinetic model TII (BP) proposed by Behar et al. (1997) was used to simulate the hydrocarbon generation upon thermal maturation of kerogen in potential source rocks.

The Petroleum System Elements (PSE) listed in tables 1 and 2 for each well is based on lithology data reported by Premarathne (2015) and unpublished well completion reports held at Petroleum Resources Development Secretariat (PRDS). When entering the PSE into PetroMod 1D software, there was a limitation, which prevented entering the same lithology unit to act as a source rock and a seal simultaneously. A generalized petroleum system event chart for the Sri Lankan sector of the Cauvery was prepared based on lithology information in Cantwell et al. (1978); Premarathne (2015) and unpublished reports, porosity and permeability data available in Shaw (2001) and simulations of hydrocarbon generation rates in this study. Model validation was carried out using the kerogen maturation profiles presented in Cantwell et al. (1978) for the four wells. The method used to validate the model is described in detail in Premarathne (2020).

\section{RESULTS AND DISCUSSION}

\section{Timing of Hydrocarbon Generation and Expulsion}

Albian shale penetrated by the Pesalai-1 well generating oil in two phases, the first phase from the Maastrichtian to Campanian and the second phase from the Early Miocene to Recent (Fig. 2).
In the first phase, hydrocarbon is generated at a maximum rate of $0.1 \mathrm{mgHC} / \mathrm{gTOC} / \mathrm{Ma}$ around $70 \mathrm{Ma}$, while in the second phase at 0.2 $\mathrm{mgHC} / \mathrm{gTOC} / \mathrm{Ma}$ around $10 \mathrm{Ma}$ (Fig 2). In other words, the maximum rate achieved in the second phase is twice the maximum rate observed in the first phase. The generation rate in the second phase continuously diminishes from $10 \mathrm{Ma}$ to Recent (Fig. 2). This may be due to the exhaustion of the genetic potential of kerogen. Late Cretaceous sediments penetrated by the Pesalai-1 well also generate hydrocarbons at a maximum rate of $0.05 \mathrm{mgHC} / \mathrm{gTOC} / \mathrm{Ma}$ during the second phase. However, hydrocarbons expelled from these stratigraphic intervals are less than 0.0005 metric tons (see Fig. 3). The rate of hydrocarbon generation in Cretaceous sediments penetrated by the Palk Bay-1, Delft-1, and Pedro-1 wells are less than 0.01 $\mathrm{mgHC} / \mathrm{gTOC} / \mathrm{Ma}$ (Figs. 4, 5 \& 6). This is mainly due to the thermal immaturity of the potential source rocks penetrated by the three wells.

\section{Hydrocarbon Source Rocks}

According to Premarathne (2015), Albian claystone penetrated by the Pesalai-1 well has the TOC ranging from 6.9 to $2.9 \%$ and $\mathrm{HI}$ values around $100 \mathrm{mg} \mathrm{HC/g}$ TOC; Albian sediments recovered from the Delft- 1 and Pedro- 1 wells have average TOC values of $2.1 \%$ and $0.85 \%$, respectively and $\mathrm{HI}$ values 98 and $32 \mathrm{mg} \mathrm{HC} / \mathrm{g}$ TOC, respectively; Maastrichtian to Campanian claystone penetrated by the Palk Bay-1 well has TOC of $0.5 \%$ and HI values of $102 \mathrm{mg} \mathrm{HC} / \mathrm{g}$ TOC.

Based on the above-mentioned TOC and HI values, the thermal maturity data and the hydrocarbon generation rates simulated in this study, it is obvious that Albian shale, particularly in the Pesalai area in the Sri Lankan sector, has relatively a higher hydrocarbon source potential. Coincidently, Albian shale is considered to be the main source of oil and natural gas discovered in the Ramnad-Palk BayNagapattinam depression under Indian Jurisdiction (Chandra et al., 1991; Murthy et al., 2008). Pre-Albian to Cenomanian sediment in the Indian sector, have relatively TOC and HI ranging $0.53-3.05 \%$ and $33-280 \mathrm{mg} \mathrm{HC} / \mathrm{g}$ TOC, respectively, (Chandra et al., 1991). 


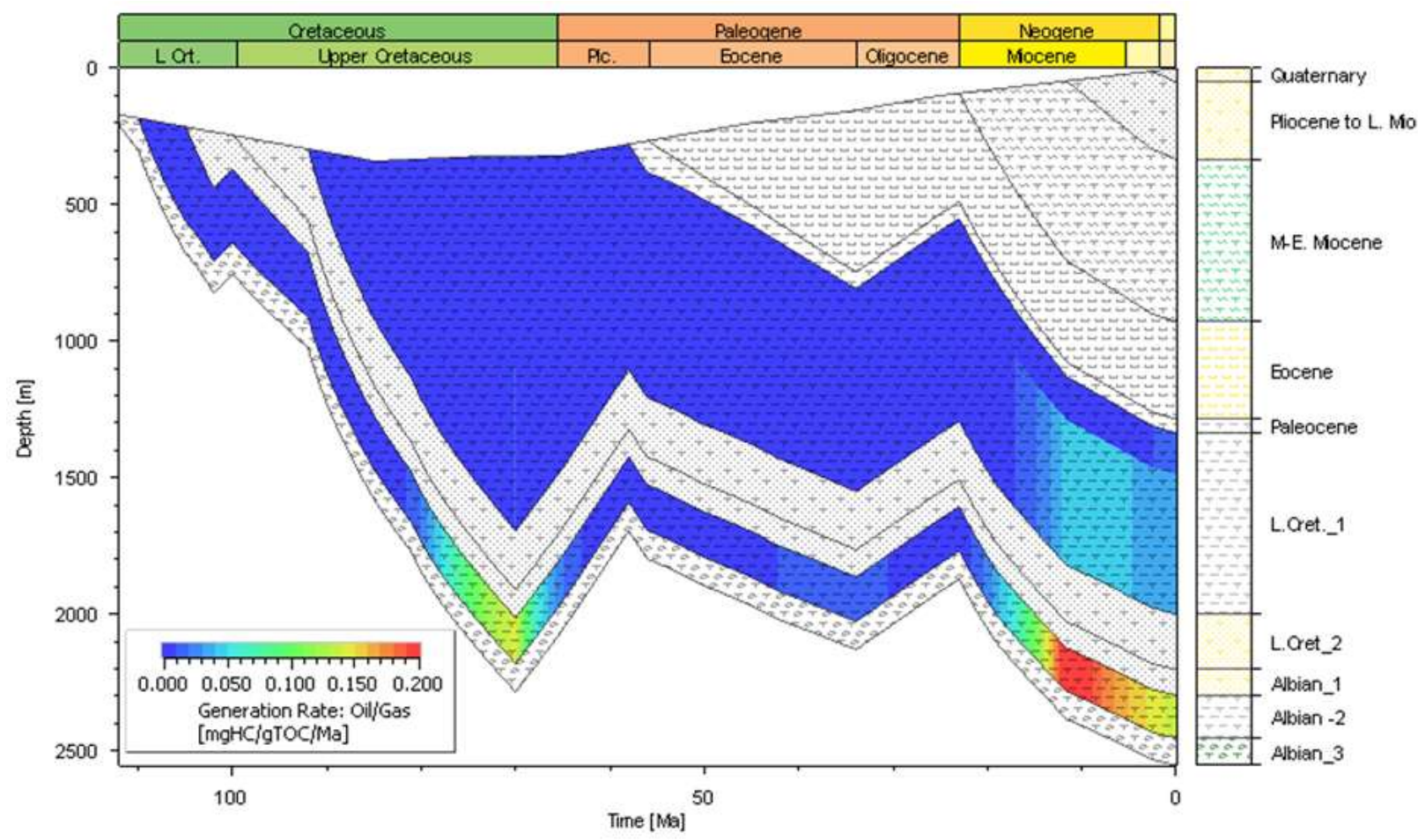

Fig. 2. Burial history plot for the Pesalai-1 well showing the rate of hydrocarbon generation in source rocks, which appear in blue.

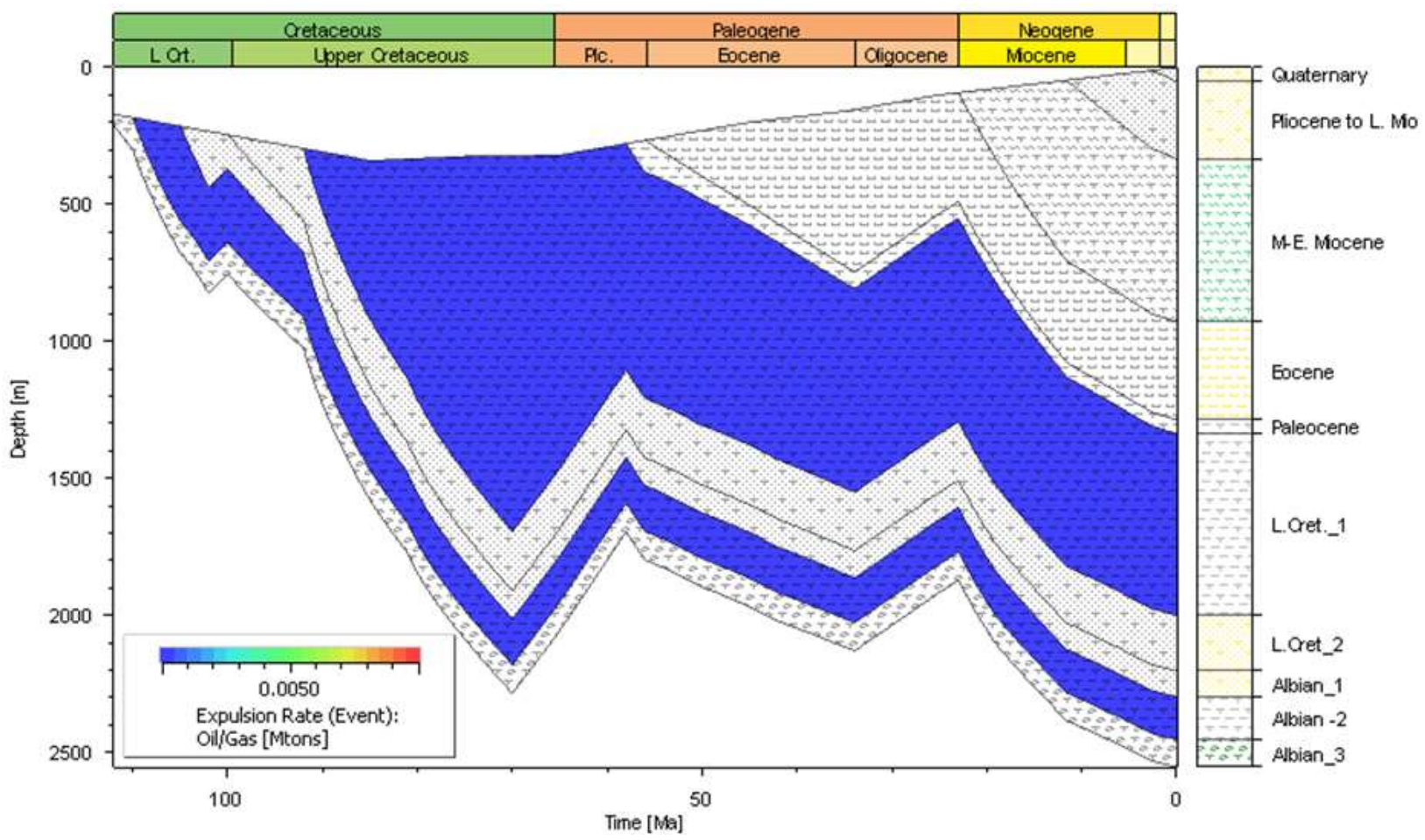

Fig. 3. Burial history plot for the Pesalai-1 well-showing amount of hydrocarbon expelled from potential source rocks. 


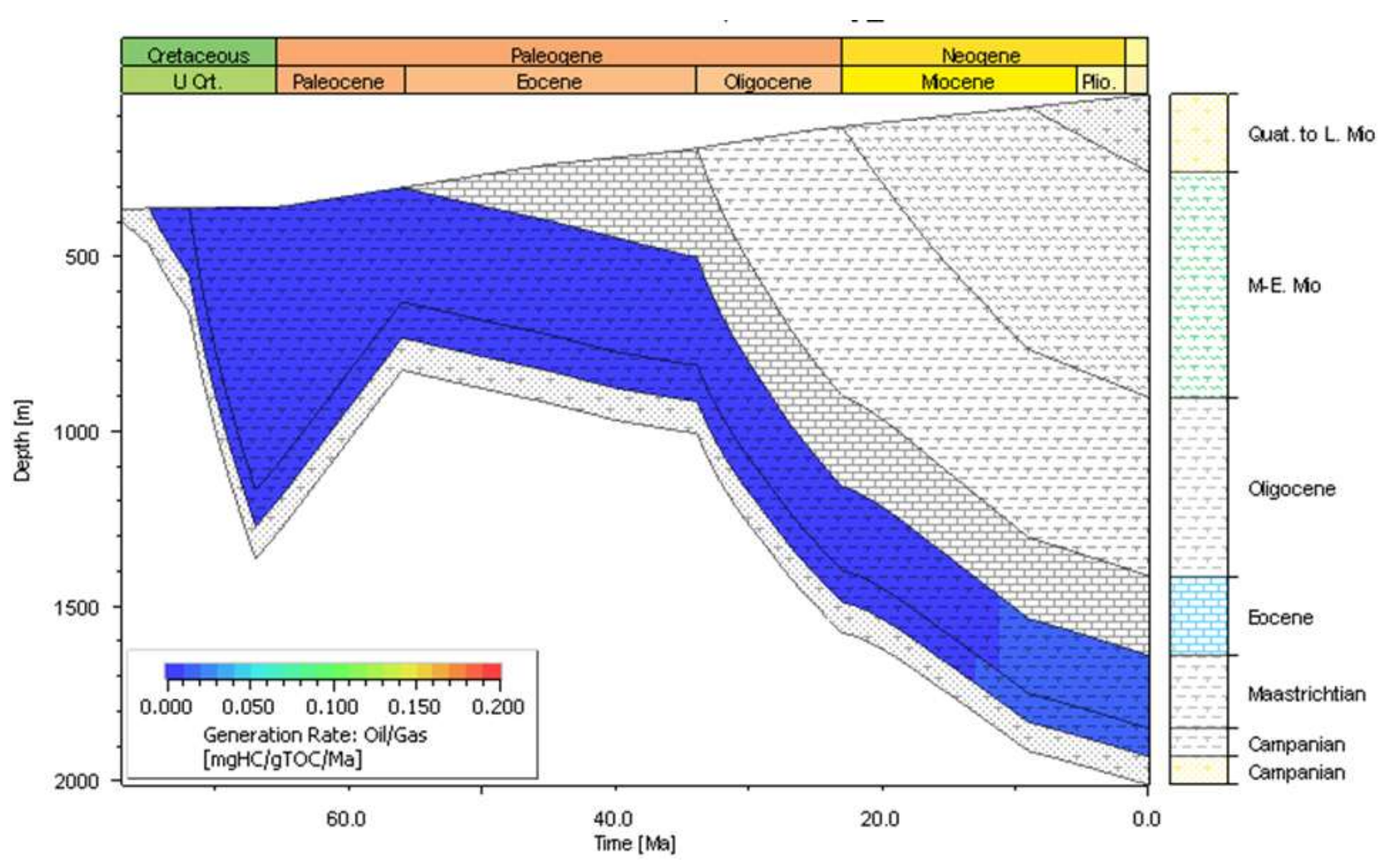

Fig. 4. Burial history plot showing the rate of hydrocarbon generation in source rocks penetrated by the Palk-Bay-1 well.

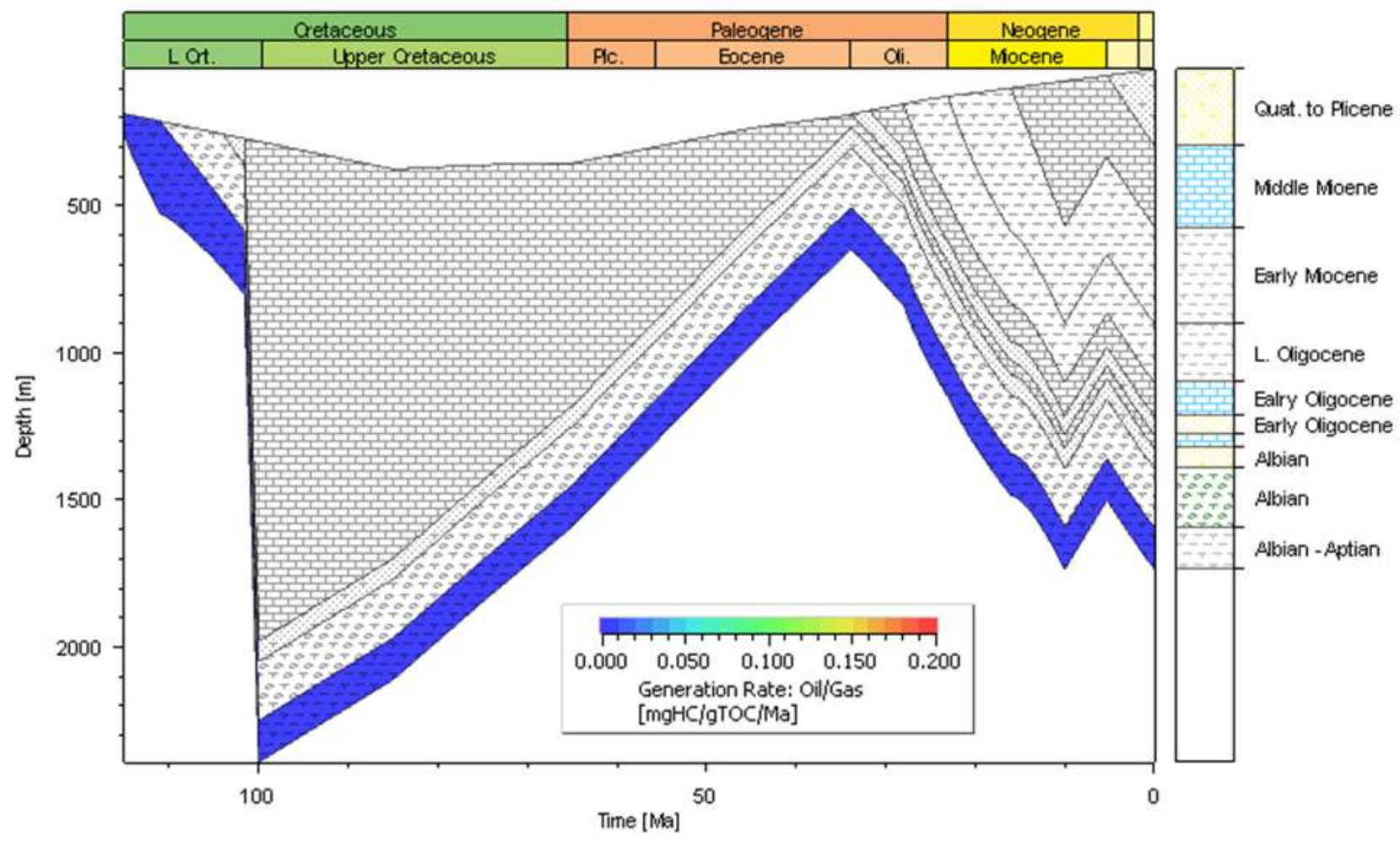

Fig. 5. Burial history plot showing the rate of hydrocarbon generation in source rocks penetrated by the Delft-1 well. 


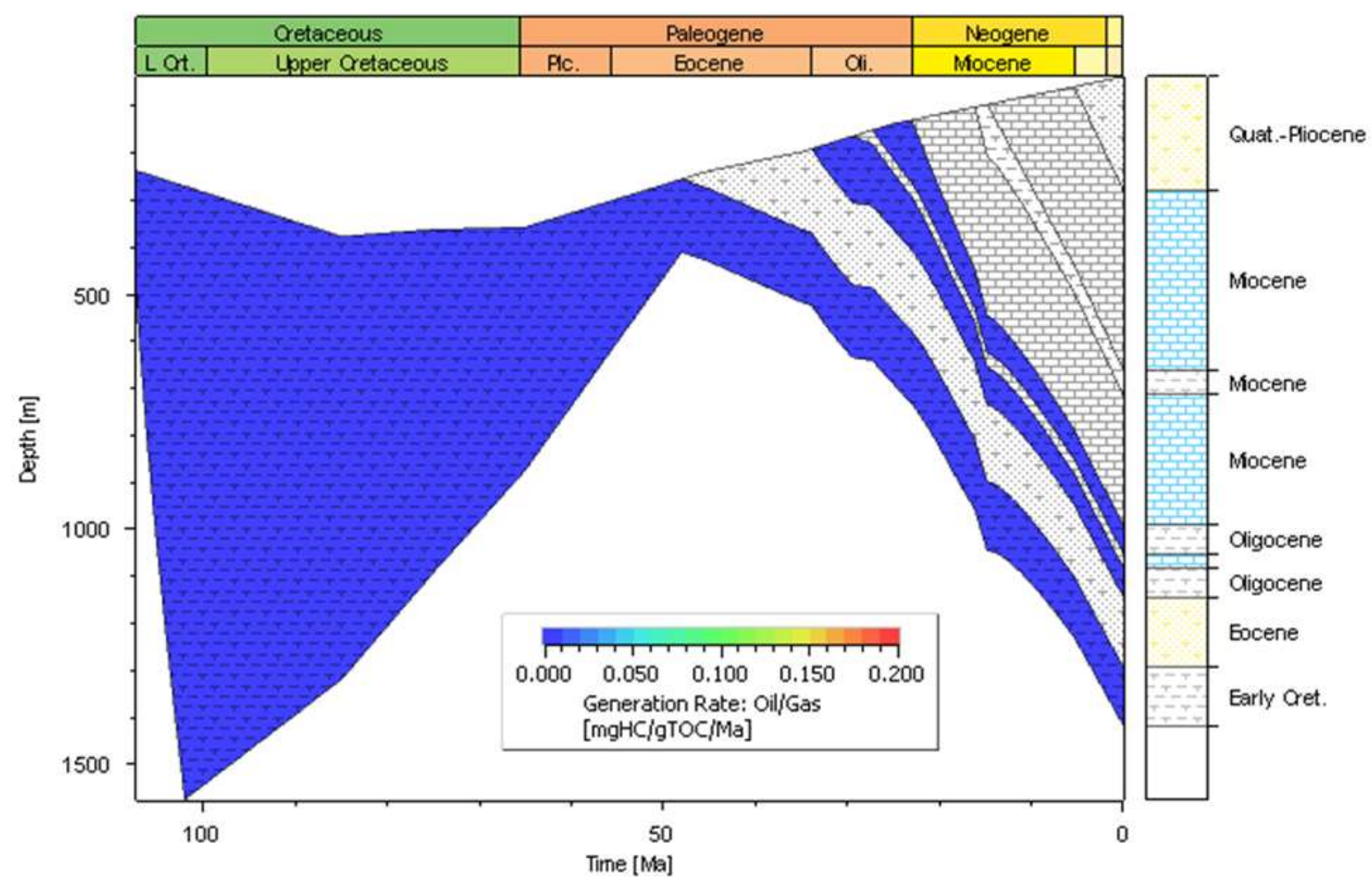

Fig. 6. Burial history plot showing the rate of hydrocarbon generation in source rocks penetrated by the Pedro-1 well.

The presence of both types II and III kerogens in sediments (Premarathne, 2015) indicates that the Cauvery Basin in Sri Lanka has the potential to produce both oil and natural gas upon thermal maturity. But, the kerogen maturation profiles and generalized stratigraphic columns appear in Figs. 2, 4, 5, \& 6 show that the potential source rocks penetrated by the four wells have never been buried to sufficient depths for them to reach the gas window throughout the depositional history of the basin.

\section{Hydrocarbon Traps and Seals}

A wide variety of trapping mechanisms in the Sri Lankan sector of the Cauvery Basin are evident in the seismic coverage over the basin (Cantwell et al., 1978; Shaw, 2001). They include rotated fault blocks formed during the syn-rift period (130-90 Ma) of the basin (Shaw, 2001), anticlinal closures formed due to basin inversion continued through the Oligocene (Premarathne et al., 2016) and stratigraphic pitchouts and channel fills (Cantwell et al., 1978).
Stratigraphic sections of the wells (Figs. 4, $5 \&$ 6) indicate that the potential reservoirs, in the Cretaceous, Eocene, Oligocene, and Miocene stratigraphic sections, are underlain by sufficiently thick fine-grained sediments that could act as potential hydrocarbon seals.

\section{Potential Reservoirs}

Figs. 4, 5 \& 6 indicate that Albian and Late Cretaceous source rocks are underlain by clastic and carbonates potential reservoirs in the Cretaceous, Eocene, Oligocene, and Miocene sections. The Cretaceous section has sandstone reservoirs, the Eocene and Oligocene sections have both carbonate and sandstone reservoirs and the Miocene section has carbonate reservoirs. Shaw, (2001), based on the interpretation of wireline logs run on the wells drilled in the Sri Lankan sector of the Cauvery Basin, concludes that sandstone and limestone deposited in the above mentioned stratigraphic intervals have good porosity and permeability. When considering the stratigraphic thinness and the timing of deposition of the potential reservoir rocks and the timing of the formation of structural traps, it is apparent that Albian and 
Late Cretaceous sandstones could be the most potential hydrocarbon reservoirs in the Sri Lankan sector of the Cauvery Basin. Coincidently, oil and natural gas deposits already discovered in the Indian side of the Ramnad-Palk-Bay-Nagapattinam depression have been accumulated in Albian sandstones (Chandra et al., 1991).

\section{Hydrocarbon Migration}

Lack of lateral reservoir continuity could be expected due to the division of the basin into sub-basins/ depressions by basement ridges. The occurrence of potential reservoirs approximately 1000 to $1500 \mathrm{~m}$ vertically above the oil window invokes substantial vertical hydrocarbon migration. The burial history modeling in Premarathne (2020) demonstrates the importance of deep syn-rift faulting as a means of providing vertical conduits into potential reservoir units located above the oil window.

\section{Chances of Occurring an Active Petroleum System}

The most probable petroleum system that could encounter in the Sri Lanka sector of the Cauvery Basin is summarised in the Petroleum System Evet (PSE) chart given in Fig. 7. It was prepared based on the data and modelling result of only 4 wells located mainly in the north-western part of the onshore and offshore areas under the Sri Lankan jurisdiction. Delft-1 and Pedro-1 wells were drilled on structural highs (Fig. 1). This could be the reason for their relatively thin stratigraphic columns.

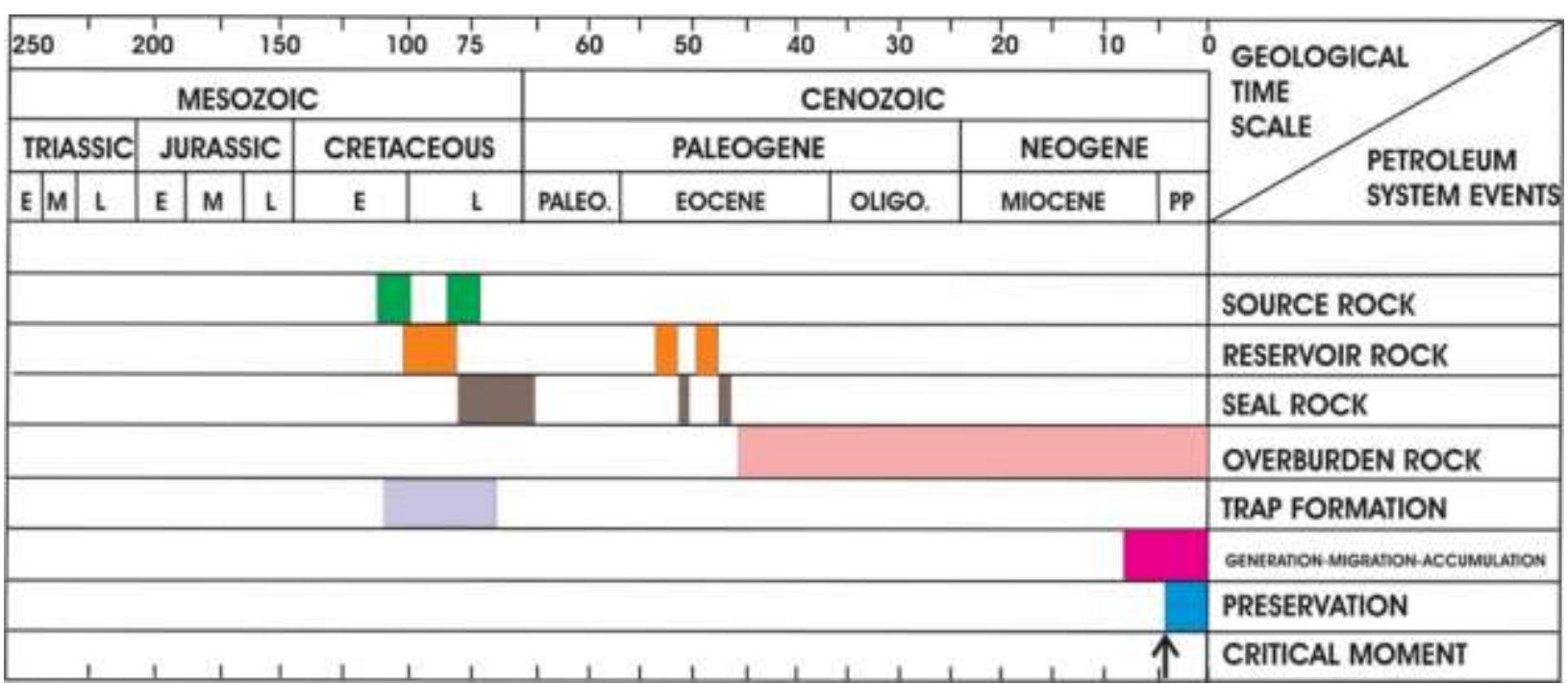

Fig. 7. Petroleum system events chart for the most probable petroleum system in the Sri Lankan sector of the Cauvery Basin. Paleo. $=$ Paleocene, Oligo. $=$ Oligocene, $P P=$ Pliocene and Pleistocene, $E=$ Early, $M=$ middle and $L=$ Late

A basement depth isopach map of the Sri Lankan sector of the Cauvery Basin, generated using seismic data, shows that the stratigraphic thickness at some places in the Pesalai-Palk-Bay depression reaches $3000 \mathrm{~m}$ (Cantwell et al., 1978). In line with this observation, the Pesalai3 well researched a total depth of $2850 \mathrm{~m}$. Kerogen maturation Profiles available in Premarathne (2020) show that the thermal maturity of sediments currently buried at 2800 $\mathrm{m}$ depth has reached the vitrinite reflectance value of around $0.7 \% \mathrm{R}_{\mathrm{o}}$. Therefore, it is possible that Cretaceous potential source rocks at that depths had generated and expelled a significant quantity of hydrocarbons. A large part of the north and north-eastern offshore area of Sri
Lanka remains underexplored. As a result, the petroleum geology of this area is relatively unknown. There is a possibility that the petroleum system in the Indian side of the Ramnad-Palk Bay-Nagapattinam depression extends towards the north and north-eastern parts of Sri Lanka. One of the main barriers to lateral extension of the petroleum systems is the Mandapam-Delft ridge (Fig 1). However, whether the ridge continues to extend towards the north-east direction is not known clearly due to the lack of data availability. More exploration wells and high-resolution seismic coverage are required to fully understand and to prove the existence of an active petroleum system in the Sri Lankan sector of the Cauvery Basin 


\section{CONCLUSIONS}

Albian and Late Cretaceous sediments are the most potential hydrocarbon source rocks occur in the Sri Lankan sector of the Cauvery Basin. Hydrocarbon potential in the Pesalai area is relatively higher than that in the Palk-Bay area. Hydrocarbon exploration in the Sri Lankan sector of the Cauvery Basin should mainly target Cretaceous and Eocene clastic and carbonate reservoirs in faults and anticlinal traps.

\section{ACKNOWLEDGEMENTS}

The author is thankful to the Director-General of Petroleum Resources Development Secretariat (PRDS), for providing data and granting permission to publish this work; to Preeni Vithanage, Chaminda Kularathne, and Damsith Weerasinghe at PRDS for their myriad support.

\section{REFERENCES}

Baillie, P.W., Shaw, R.D., Liyanaarachchi, D.T.P., and Jayaratne, M.G. (2002) A new Mesozoic sedimentary basin, offshore Sri Lanka. Proceedings of EAGA $64^{\text {th }}$ Conference \& Exhibition, Florence, Italy, 4p.

Bandara, A.S., Weerasinghe, D.A., and Ratnayake, A.S. (2020) Determination of the regional and residual gravity anomalies to reconstruct basin structures of the Cauvery Basin. Journal of Geological Society of Sri Lanka Vol. 21(1), pp 21-31.

Bastia, R. and Radhakrishna, M. (2012). Basin Evolution and Petroleum Prospectivity of the Continental Margins of India. Elsevier. Volume, 59, 432p

Behar, F., Vandenbroucke, M., Tang, Y., Marquis, F., and. Espitalie, J. (1997) Thermal cracking of kerogen in open and closed systems: determination of kinetic parameters and stoichiometric coefficients for oil and gas generation. Organic Geochemistry. Volume 26, 5-6, pp 321-339.

Cantwell, T., Brown, T.E. and Mathews, D.G. (1978) Petroleum Geology of the Northwest Offshore Area of Sri Lanka. Proceedings of South Asian Petroleum Society Session, Singapore, pp 21-32.

Chandra, K., Philip, P.C., Sridharan, P., Chopra, V.S., Rao, B. and Saha, P.K. (1991) Petroleum source-rock potentials of the Cretaceous transgressive-regressive sedimentary sequences of the Cauvery
Basin. Journal of Southeast Asian Earth Sciences, 5 (1-4), pp 367-371.

Chakraborty, N. and Sarkar, S. (2018) Synsedimentary tectonics and facies analysis in a rift setting: Cretaceous Dalmiapuram Formation, Cauvery Basin, SE India. Journal of Palaeogeography, 7(2), pp 146167.

Chari, N.M.V., Sahu, J.N., Bnerjee, B., Zutshi, P.L., and Kuldeep, C. (1995) Evolution of the Cauvery Basin, India from subsidence modeling. Marine and Petroleum Geology, 12(6), pp 667-675.

Chaudhuri, A., Rao, M.V., Dobriyal, J.P., Saha G.C., Chidambaram, L. Mehta, A.K., Ramana L.V. and Murthy, K.S. (2010) Prospectivity of Cauvery Basin in Deep Syn-rift Sequences, SE India. AAPG Search and Discovery Article \#10232.

Desa, M.A., Isamaiel, M., \& Krishna, K.S. (2018). Oblique strike-slip motion off the Southeastern Continental Margin of India: Implication for the separation of Sri Lanka from India, Journal of Asian Earth Sciences. 156c, pp 111-121, https://doi.org/10.1016/j.jseaes.2018.01.015.

Gibbons, A. D., Whittaker, J. M., Müller, R. D. (2013) The breakup of East Gondwana: Assimilating constraints from Cretaceous ocean basins around India into a best-fit tectonic model. Journal of Geophysical Research: Solid Earth, Vol. 118, pp 808822, doi:10.1002/jgrb.50079, 2013.

Katz, M.B., (1978). Sri Lanka in Gondwanaland and the evolution of the Indian Ocean. Geological Magazine, 115, pp 237-244.

Lal, N.K., Siawal, A. and Kaul, A.K. (2009) Evolution of east coast of India-A plate tectonic reconstruction. Journal Geological Society of India, 73, pp 249-260.

Mohapatra, P., Srinivas, M., Kumar, N., Routray, P., Adhikari, S. and Daly, C. (2012) The geology and petroleum systems of the Mannar Basin, Sri Lanka. Proceedings of AAPG International Conference \& Exhibition, Singapore.

Murthy, K.S., Chaudhuri, A., Ramana, L.V, Rao, M.V., and Dobriyal, J.P (2008) Hydrocarbon Exploration of Syn Rift Sediments in Nagapattinam Sub Basin, Cauvery Basin - A Case Study. $7^{\text {th }}$ biannual exhibition and conference on geophysics, Hyderabad, 443p.

Premarathne, D.M.U.A.K. (2008). Petroleum Potential of Sri Lankan Cauvery Basin. Proceedings of $24^{\text {th }}$ Annual technical 
sessions of the Geological Society of Sri Lanka, Colombo, pp 7.

Premarathne, D.M.U.A.K., Suzuki, N., Rathnayake, N.P., and Kularathne, E.K.C.W. (2013) A petroleum system in the Gulf of Mannar Basin, offshore Sri Lanka. Proceedings of 29th annual technical sessions of Geological Society of Sri Lanka, Peradeniya, pp 9-12.

Premarathne, U. (2015) Petroleum Potential of the Cauvery Basin, Sri Lanka, Journal of the Geological Society of Sri Lanka, 17, pp 4152.

Premarathne, U., Suzuki, N., Ratnayake, N. and Kularathne, C. (2016) Burial and thermal history modeling of the Mannar Basin, offshore Sri Lanka. Journal of Petroleum Geology, 39(2), pp 193-214.

Premarathne, U. (2017) Present-day heat flows in the Cauvery basin, Sri Lanka. Proceedings of $33^{\text {rd }}$ annual technical sessions of Geological Society of Sri Lanka, pp 18.

Premarathne, U., 2020. Burial and thermal history of the Cauvery Basin, Sri Lanka: ABasin Modeling Approach. Journal of Geological Society of Sri Lanka. 21 (1), pp 33-45.

Ramana, M.V., Subrahmanyam, V., Sarma, K.V.L.N.S. and Seshavataram, B.T.V. (1995) Marine magnetic studies over a lost wellhead in Palk Bay, Cauvery Basin, India. Journal of the Geological Society of India, 45(2), pp 201-208.

Rana, M.S., Chakraborty, C., Sharma, R. and Giridhar, M. (2008) Mannar volcanicsimplications for Madagascar breakup. Proceedings of $7^{\text {th }}$ International Conference and Exposition on Petroleum Geophysics, Hyderabad.

Raju, D.S.N., Reddy, A.N., Jaiprakash, B.C., Gilbert, H. and Sangwar, D.P. (2018) Age and Paleoenvironmental Evolution of the Syn-rift Fill Sediments in East Coast Basins of India, Oil and Natural Gas Company Bulletin, 52(2), pp 127-148

Rao, M.V., Chidambaram, L., Bharktya, D. and Janardhanan, M. (2010) Integrated analysis of Late Albian to Middle Miocene sediments in Gulf of Mannar shallow waters of the Cauvery Basin, India: A sequence stratigraphic approach. Proceedings of $8^{\text {th }}$ biennial international conference and exposition on petroleum geophysics, Hyderabad.
Ratheesh-Kumar, R.T., Dharmapriya, P.L., Windley, B.F., Xiao, W.J., and Jeevan, U. (2020) The tectonic "Umbilical Cord" linking India and Sri Lanka, and the tale of their failed rift. Journal of Geophysical Research: Solid Earth, 125(5): DOI: 10.1029/2019JB018225.

Sastri, V.V. Sinha, R.N., Singh, G. and Murti, K.V.S. (1973). Stratigraphy and tectonics of sedimentary basins on the east coast of peninsular India, AAPG Bull, 57, pp 655678.

Sastri, V.V., Venkatachala, S.B.S. and. Narayananthe, V. (1981) Evolution of the East Coast of India. Paleogeography, Palaeoclimatology, Palaeoecology, 36, pp 23-54

Shaw, R. (2001) Review of Sri Lanka's hydrocarbon prospects: Promotion of Private Sector Involvement in Oil and Gas Exploration. An unpublished report held at Petroleum Resources Development Secretariat. 70. 